\title{
FAKTOR-FAKTOR YANG BERHUBUNGAN DENGAN LAMA PERAWATAN PASIEN PASCA OPERASI DI RUANG RAWAT INAP BEDAH RUMAH SAKIT
}

\author{
El Rahmayati*, Zaid Al Asbana**, Aprina* \\ *Dosen Jurusan Keperawatan Potekkes Tanjungkarang \\ **Alumnus Jurusan Keperawatan Poltekkes Tanjungkarang
}

\begin{abstract}
Data Tabulasi Nasional Departemen Kesehatan Republik Indonesia Tahun 2009, menjabarkan bahwa tindakan bedah menempati urutan ke-11 dari 50 pola penyakit di Indonesia dengan persentase $12,8 \%$. Pasien yang sudah dilakukan tindakan pembedahan kemudian dirawat di ruang pemulihan dan dilakukan transport pasien kembali di ruang rawat inap bedah. Di RSUD Dr. H Abdul Moeloek pasien pasca operasi terbesar adalah pasien yang dengan lama rawat inap lebih dari 5 hari yaitu $(65,5 \%)$ responden. Tujuan dari penelitian ini untuk mengetahui faktor-faktor yang berhubungan dengan lama perawatan pasien pasca operasi di ruang rawat inap bedah Rumah Sakit Dr. H. Abdul Moeloek. Jenis penelitian ini kuantitatif dengan rancangan survey analitik dan pendekatan cross sectional. Teknik pengambilan sampel menggunakan teknik Purposive Sampling. Populasi pasien post operasi di Rumah Sakit Dr. H Abdul Moeloek adalah 58 pasien. Berdasarkan hasil perhitungan sampel yang digunakan yaitu total populasi dengan 58 responden. Pengumpulan data menggunakan lembar observasi dengan menggunakan uji ChiSquare. Hasil penelitian didapatkan adanya dua faktor yang berhubungan dengan lama rawat inap yaitu jenis operasi dengan nilai $\rho$ value $=0.024$ sedangkan nilai $\mathrm{OR}=3,704(1,151-11,918)$ dan diagnosa penyakit penyerta dengan nilai $\rho$ value $=0.049$ sedangkan nilai $\mathrm{OR}=(6,786(0,801-57,478)$. Sedangkan yang tidak berhubungan terdapat tiga faktor yaitu infeksi luka operasi dengan nilai $\rho$ value $=0,114$, jenis penyakit dengan nilai $\rho$ value $=0,301$, dan umur penderita $\rho$ value $=0.636$. Peneliti berharap agar faktor faktor yang dapat mempengaruhi lama rawat pasien pasca operasi tetap di perhatikan supaya tidak terjadi perawatan yang tidak sesuai dengan lama rawat pasien pasca operasi.
\end{abstract}

\section{Kata Kunci: Lama Rawat, Pasca Operasi, Jenis Operasi, Penyakit Penyerta}

\section{LATAR BELAKANG}

Dewasa ini pasien yang mendapat tindakan operasi bedah semakin meningkat. Pembedahan merupakan semua tindakan pengobatan yang menggunakan cara infasif dengan membuka atau menampilkan bagian tubuh yang akan ditangani (Sjamsu hidajat \& Win de Jong, 2005 dalam Praditha, 2016). Data WHO menunjukkan bahwa selama lebih dari satu abad, perawatan bedah telah menjadi komponen penting dari perawatan kesehatan di seluruh dunia. Diperkirakan setiap tahun ada 230 juta tindakan bedah dilakukan di seluruh dunia (Hasri, 2012 dalam Kusumayanti dkk, 2013). Data Tabulasi Nasional Departemen Kesehatan Republik Indonesia Tahun 2009, menjabarkan bahwa tindakan bedah menempati urutan ke-11 dari 50 pola penyakit di Indonesia dengan persentase
$12,8 \%$. Pasien yang sudah dilakukan tindakan pembedahan kemudian dirawat di ruang pemulihan dan dilakukan transport pasien kembali di ruang rawat inap bedah.

Lama rawat (Length of Stay/LOS) adalah salah satu indikator dalam menilai mutu dan efisien dari rumah sakit (Tedja, 2011). Menurut (Depkes, 2011 dalam Wartawan, 2012) di Indonesia, rata-rata lama hari rawat dari tahun 2003 sampai 2009 masih belum ideal karena tergolong pendek yaitu berkisar antara 4 sampai 5 hari.

Lama perawatan di ruang bedah tentunya berhubungan dengan faktorfaktor yang mempengaruhi perawatan. Beberapa faktor baik yang berhubungan dengan keadaan klinis pasien, tindakan medis, pengelolaan pasien di ruangan maupun masalah adminstrasi rumah sakit bisa mempengaruhi terjadinya penundaan pulang pasien. Ini akan mempengaruhi 
LOS. Terutama untuk pasien yang memerlukan tindakan medis atau pembedahan (Wartawan, 2012). Faktorfaktor yang berpengaruh tersebut antara lain: komplikasi atau infeksi luka operasi, jenis operasi, jenis kasus atau penyakit, tenaga dokter yang menangani atau pelaksana operasi, hari masuk Rumah Sakit, hari pulang dari Rumah Sakit, umur penderita, pekerjaan, jenis penanggung biaya, alasan keluar dari Rumah Sakit, pemeriksaan penunjang medis, pemilikan, kebijakan dan kegiatan administrasi Rumah Sakit, serta kelas perawatan yang di pilih

Berdasarkan hasil data laporan kegiatan di Rumah Sakit Abdul Moeloek Provinsi Lampung pada tahun 2014 jumlah total lama rawat inap yaitu 154.788 hari dengan jumlah tempat tidur total adalah 600 tempat tidur dengan semua kelas perawatan. Pada data laporan kegiatan Rumah Sakit Abdul Moeloek terbagi jadi beberapa IRNA, salah satu nya pada IRNA I terdiri dari 5 ruangan bedah yaitu ruang Mawar, Kutilang, Gelatik, Kemuning, dan Anggrek. Pada IRNA I terdiri dari 2 kelas perawatan yaitu kelas II dan kelas III yang masing masing mempunyai tempat tidur yaitu 41 tempat tidur untuk kelas II dan 119 tempat tidur untuk kelas III dengan jumlah total 160 tempat tidur untuk pasien rawat inap bedah di Rumah Sakit Abdul Moeloek. Berdasarkan hasil pre survey pada tanggal 25 januari 2017 jumlah ratarata pasien pasca operasi yang dirawat di ruang rawat inap bedah periode juli sampai desember 2016 yaitu 58 orang pasien perbulannya.

\section{METODE}

Jenis penelitian ini adalah penelitian kuantitatif dengan rancangan survey analitik dan pendekatan cross sectional. Populasi dalam penelitian adalah semua pasien post operasi di ruang Kutilang dan Gelatik RSUD Dr. H. Abdul Moeloek Provinsi Lampung. Sampel dalam penelitian ini adalah total populasi sebanyak 58 orang. Waktu pelaksanaan penelitian yaitu $20 \mathrm{Mei}$ 2017 sampai 20 Juni 2017 di ruang Kutilang dan Gelatik RSUD Dr. H. Abdul Moeloek.

Instrumen pengumpulan data dalam penelitian ini dilakukan dengan menggunakan lembar observasi yang oleh peneliti yang diambil dari penelitian. Lembar observasi tersebut yaitu berisi tentang Infeksi luka pasca operasi, jenis operasi, jenis penyakit, umur penderita, dan diagnosis penyakit penyerta serta lama perawatan pasien dirawat diruang rawat inap setelah operasi.

\section{HASIL}

\section{Analisis Univariat}

Tabel 1: Hubungan Antara Infeksi Luka Operasi Dengan Lama Perawatan Pasien Pasca Operasi

\begin{tabular}{lcccccc}
\hline \multirow{2}{*}{$\begin{array}{c}\text { Infeksi Luka } \\
\text { Operasi }\end{array}$} & \multicolumn{4}{c}{ Lama Rawat Inap } & \multirow{2}{*}{ Total } \\
\cline { 2 - 6 } & \multicolumn{2}{c}{5 hari } & $\leq 5$ hari & & \\
\cline { 2 - 6 } & $\mathrm{f}$ & $\%$ & $\mathrm{f}$ & $\%$ & $\mathrm{f}$ & $\%$ \\
\hline Ada & 14 & 82,4 & 3 & 17,6 & 17 & 100 \\
\hline Tidak ada & 25 & 61,0 & 16 & 39,0 & 41 & 100 \\
\hline Total & 39 & 67,2 & 19 & 32,8 & 58 & 100 \\
\hline$p$ value & & & 0,114 & & \\
\hline
\end{tabular}

Berdasarkan hasil penelitian pada tabel 1 menunjukkan bahwa responden terbanyak adalah lama rawat inap lebih dari 5 hari dengan tidak ada infeksi luka operasi sebanyak $(61,0 \%)$ responden. Hasil penelitian ini bahwa pasien pasca operasi yang tidak ada infeksi luka operasi lebih cenderung lama rawat inap lebih dari 5 hari di ruang rawat inap bedah.

Hasil uji statistik dengan menggunakan chi square dapat diperoleh nilai yaitu $\rho$ value $=0,114$ yang berarti $\rho>a$, maka dapat disimpulkan bahwa tidak ada hubungan antara infeksi luka operasi dengan lama perawatan pasien pasca operasi di ruang rawat inap bedah Rumah Sakit Dr. H Abdul Moeloek. 
Tabel 2: Hubungan antara Jenis Operasi dengan Lama Perawatan Pasien Pasca Operasi

\begin{tabular}{|c|c|c|c|c|c|c|}
\hline \multirow{3}{*}{ Jenis Operasi } & \multicolumn{4}{|c|}{ Lama Rawat Inap } & \multirow{2}{*}{\multicolumn{2}{|c|}{ Total }} \\
\hline & \multicolumn{2}{|c|}{$>5$ hari } & \multicolumn{2}{|c|}{$\leq 5$ hari } & & \\
\hline & $\mathrm{f}$ & $\%$ & $\mathrm{f}$ & $\%$ & $\mathrm{f}$ & $\%$ \\
\hline Mayor & 30 & 76,9 & 9 & 23,1 & 39 & 100 \\
\hline Minor & 9 & 47,4 & 10 & 52,6 & 19 & 100 \\
\hline Total & 39 & 67,2 & 19 & 32,8 & 58 & 100 \\
\hline$p$ value & \multicolumn{6}{|c|}{0,024} \\
\hline OR CI ;95\% & \multicolumn{6}{|c|}{$3,704(1,151-11,918)$} \\
\hline
\end{tabular}

Berdasarkan hasil penelitian pada tabel 2 menunjukkan bahwa responden terbanyak adalah lama rawat inap lebih dari 5 hari dengan jenis operasi mayor sebanyak $(76,9 \%)$ responden. Hasil penelitian ini bahwa pasien pasca operasi yang jenis operasi mayor lebih cenderung lama rawat inap lebih dari 5 hari di ruang rawat inap bedah.

Hasil uji statistik dengan menggunakan chi square dapat diperoleh dari nilai $\rho$ value $=0.024$ yang berarti $\rho<a$, maka dapat disimpulkan bahwa ada hubungan antara jenis operasi dengan lama perawatan pasien pasca operasi di ruang rawat inap bedah Rumah Sakit Dr. H Abdul Moeloek, dengan nilai $\mathrm{OR}=3,704$ $(1,151-11,918)$ artinya responden dengan jenis operasi mayor berpeluang 3,7 kali lebih lama untuk perawatan pasca operasi di ruang rawat inap bedah.

Tabel 3: Hubungan antara Jenis Penyakit dengan Lama Perawatan Pasien Pasca Operasi

\begin{tabular}{lcccccc}
\hline \multirow{3}{*}{ Penyakit } & \multicolumn{4}{c}{ Lama Rawat Inap } & \multirow{2}{*}{ Total } \\
\cline { 2 - 6 } & \multicolumn{2}{c}{$>$ hari } & $\leq 5$ hari & & \\
\cline { 2 - 6 } & $\mathrm{f}$ & $\%$ & $\mathrm{f}$ & $\%$ & $\mathrm{f}$ & $\%$ \\
\hline Penyakit Kronis & 20 & 74,1 & 7 & 25,9 & 27 & 100 \\
\hline Penyakit Akut & 19 & 61,3 & 12 & 38,7 & 31 & 100 \\
\hline Total & 39 & 67,2 & 19 & 32,8 & 58 & 100 \\
\hline$p$ value & \multicolumn{5}{c}{0,301} \\
\hline
\end{tabular}

Berdasarkan hasil penelitian pada tabel 3 menunjukkan bahwa responden terbanyak adalah lama rawat inap lebih dari 5 hari dengan penyakit kronis sebanyak $(74,1 \%)$ responden. Hasil penelitian ini bahwa pasien pasca operasi dengan penyakit kronis lebih cenderung lama rawat inap lebih dari 5 hari di ruang rawat inap bedah.

Hasil uji statistik dengan menggunakan chi square dapat diperoleh dari nilai $\rho$ value $=0,301$ yang berarti $\rho>a$, maka dapat disimpulkan bahwa tidak ada hubungan antara jenis penyakit dengan lama perawatan pasien pasca operasi di ruang rawat inap bedah Rumah Sakit Dr. H Abdul Moeloek.

Tabel 4: Hubungan Umur Penderita dengan Lama Perawatan Pasien Pasca Operasi

\begin{tabular}{lcccccc}
\hline \multirow{3}{*}{ Umur } & \multicolumn{9}{l}{ Lama Rawat Inap } & \multirow{2}{*}{ Total } \\
\cline { 2 - 6 } & \multicolumn{2}{c}{5 hari } & $\leq 5$ hari & & \\
\cline { 2 - 6 } & $\mathrm{f}$ & $\%$ & $\mathrm{f}$ & $\%$ & $\mathrm{f}$ & $\%$ \\
\hline$\geq 45$ tahun & 20 & 64,5 & 11 & 35,5 & 31 & 100 \\
\hline$<45$ tahun & 19 & 70,4 & 8 & 29,6 & 27 & 100 \\
\hline Total & 39 & 67,2 & 19 & 32,8 & 58 & 100 \\
\hline$p$ value & \multicolumn{6}{c}{0,636} \\
\hline
\end{tabular}

Berdasarkan hasil penelitian pada tabel 4 menunjukkan bahwa responden terbanyak adalah lama rawat inap lebih dari 5 hari dengan umur lebih dari 45 tahun sebanyak $(64,5 \%)$ responden. Hasil penelitian ini bahwa pasien pasca operasi dengan umur lebih dari 45 tahun lebih cenderung lama rawat inap lebih dari 5 hari di ruang rawat inap bedah.

Hasil uji statistik dengan menggunakan chi square dapat diperoleh dari nilai $\rho$ value $=0,636$ yang berarti $\rho>a$, maka dapat disimpulkan bahwa tidak ada hubungan antara umur penderita dengan lama perawatan pasien pasca operasi di ruang rawat inap bedah Rumah Sakit Dr. H Abdul Moeloek.

Tabel 5: Hubungan antara Diagnosa Penyakit Penyerta dengan Lama Perawatan Pasien Pasca Operasi

\begin{tabular}{lcccccc}
\hline \multirow{2}{*}{$\begin{array}{l}\text { Diagnosis } \\
\text { Penyakit }\end{array}$} & \multicolumn{4}{c}{ Lama Rawat Inap } & \multirow{2}{*}{ Total } \\
\cline { 2 - 6 } \multicolumn{1}{c}{ Penyerta } & $>5$ hari & $\leq 5$ hari & & \\
\cline { 2 - 6 } & $\mathrm{f}$ & $\%$ & $\mathrm{f}$ & $\%$ & $\mathrm{f}$ & $\%$ \\
\hline Dengan & 10 & 90,9 & 1 & 9,1 & 11 & 100 \\
Tanpa & 28 & 59,6 & 19 & 40,4 & 47 & 100 \\
\hline Total & 38 & 65,5 & 20 & 34,5 & 58 & 100 \\
\hline$p$ value & \multicolumn{5}{c}{0,049} \\
\hline OR CI ;95\% & \multicolumn{4}{c}{6,786} & $(0,801-57,478)$ \\
\hline
\end{tabular}


Berdasarkan hasil penelitian pada tabel 5 menunjukkan bahwa responden terbanyak adalah lama rawat inap lebih dari 5 hari dengan tanpa diagnosa penyakit penyerta sebanyak $(59,6 \%)$ responden. Hasil penelitian ini bahwa pasien pasca operasi yang tanpa diagnosa penyakit penyerta lebih cenderung lama rawat inap lebih dari 5 hari di ruang rawat inap bedah.

Hasil uji statistik dengan menggunakan chi square dapat diperoleh dari nilai $\rho$ value $=0.049$ yang berarti $\rho<a$, makan dapat disimpulkan bahwa ada hubungan antara diagnosa penyakit penyerta dengan lama perawatan pasien pasca operasi di ruang rawat inap bedah Rumah Sakit Dr. H Abdul Moeloek, dengan nilai $\mathrm{OR}=(6,786(0,801-57,478)$ artinya responden dengan diagnosa penyakit penyerta berpeluang 6,8 kali lebih lama perawatan pasca operasi diruang rawat inap bedah.

\section{PEMBAHASAN}

\section{Hubungan Infeksi Luka Operasi dengan Lama Perawatan Pasien Pasca Operasi}

Berdasarkan hasil penelitian pada tabel 1 menunjukkan bahwa responden terbanyak adalah lama rawat inap lebih dari 5 hari dengan tidak ada infeksi luka operasi sebanyak $(61,0 \%)$ responden. Hasil penelitian ini bahwa pasien pasca operasi yang tidak ada infeksi luka operasi lebih cenderung lama rawat inap lebih dari 5 hari di ruang rawat inap bedah. Hasil uji statistik dengan menggunakan chi square diperoleh nilai $\rho$ value $=0,114$ yang berarti $\rho>a$, maka dapat disimpulkan bahwa tidak ada hubungan antara infeksi luka operasi dengan lama perawatan pasien pasca operasi di ruang rawat inap bedah Rumah Sakit Dr. H Abdul Moeloek.

Menurut teori Razi \& Fakhrul, 2011 dalam Wartawan (2012) faktor-faktor yang mempengaruhi terjadinya infeksi luka operasi dan komplikasi pada umumnya, yaitu: waktu/lama operasi. Semakin lama waktu yang dibutuhkan untuk operasi maka akan mempengaruhi terhadap penyembuhan luka operasi dan juga akan meningkatkan terjadinya infeksi luka operasi, sehingga lama hari rawat akan lebih panjang. Tehnik operasi yang menyebabkan kerusakan jaringan lebih luas akan mempunyai resiko terjadinya infeksi luka operasi yang lebih besar.

Hasil penelitian ini tidak sejalan dengan hasil penelitian yang dilakukan oleh Wartawan (2012) yaitu ditemukan adanya 38 pasien yang bermasalah akibat komplikasi yang terjadi pasca operasi, dimana 27 orang pasien diantaranya mengalami penundaan pulang dari rumah sakit hingga sampai lebih dari 9 hari. Jika hal ini dibandingkan dengan pasien yang tidak mengalami komplikasi dan dianalisa dengan Chi Square didapatkanlah bahwa terjadi hubungan yang bermakna lamanya pasien dirawat di rumah sakit dengan adanya kejadian komplikasi pasca tindakan operasi .

Hal ini juga tidak sejalan dengan penelitian yang dilakukan oleh Septiani Esti Wigati, Syaifudin dengan judul Hubungan lama perawatan dengan risiko infeksi nosokomial pada pasien di ruang rawat inap RSUD Wonosari Gunung Kidul. Hasil penelitian ini menunjukkan sebagian besar lama perawatan pasien dalam kategori lama sebanyak 29 orang $(55,8 \%)$ dan sebagian besar risiko infeksi nosokomial yang terjadi dalam kategori sedang sebanyak 43 orang $(82,7 \%)$.

Menurut peneliti dari hasil penelitian yang di lakukan di ruang rawat inap bedah kejadian tidak ada infeksi luka terjadi karena tindakan aseptik dan perawatan yang baik dan benar saat, sehingga kejadian infeksi luka operasi lebih sedikit responden yang dibandingkan dengan responden yang mengalami infeksi luka operasi. Infeksi nosokomial dapat juga terjadi responden yang dirawat pasca operasi seperti keluarga pasien yang sebagian besar belum tau tentang infeksi nosokomial yang dapat mempengaruhi luka dan lama rawat pasien. Untuk itu diharapkan bagi perawat dalam tindakan terhadap pasien yang memiliki luka pasca operasi agar dapat melakukannya dalam prosedur yang baik dan benar selama tindakan sehingga luka pasien pasca 
operasi dapat sembuh sesuai dengan lama waktu perawatan yang tepat.

\section{Hubungan Jenis Operasi dengan Lama Perawatan Pasien Pasca Operasi}

Berdasarkan hasil penelitian pada tabel 2 menunjukkan bahwa responden terbanyak adalah lama rawat inap lebih dari 5 hari dengan jenis operasi mayor sebanyak $(76,9 \%)$ responden. Hasil penelitian ini bahwa pasien pasca operasi yang jenis operasi mayor lebih cenderung lama rawat inap lebih dari 5 hari di ruang rawat inap bedah. Hasil uji statistik dengan menggunakan chi square diperoleh nilai $\rho$ value $=0.024$ yang berarti $\rho<a$, maka dapat disimpulkan bahwa ada hubungan antara jenis operasi dengan lama perawatan pasien pasca operasi di ruang rawat inap bedah Rumah Sakit Dr. H. Abdul Moeloek, dengan nilai $\mathrm{OR}=3,704$ $(1,151-11,918)$ artinya responden dengan jenis operasi mayor berpeluang 3,7 kali lebih lama untuk perawatan pasca operasi di ruang rawat inap bedah.

Dari hasil teori menurut Virginia 2004 dalam (Kuraesin, 2009) operasi minor adalah operasi yang paling sering dilakukan dirawat jalan, dan dapat pulang hari yang sama. Operasi ini jarang menimbulkan komplikasi. Operasi mayor adalah operasi yang penetrates dan exposes semua rongga badan, termasuk tengkorak, termasuk pembedahan tulang, atau kerusakan signifikan dari anatomis atau fungsi faal. Operasi mayor adalah pembedahan kepala, leher, dada, dan perut (Kuraesin, 2009).

Pemulihan dapat waktu panjang dan dapat melibatkan perawatan intensif dalam beberapa hari di rumah sakit. Pembedahan ini memiliki resiko komplikasi lebih tinggi setelah pembedahan. Operasi mayor sering melibatkan salah satu badan utama di perut-cavities (laparotomy), di dada (thoracotomy), atau tengkorak (craniotomy) dan dapat juga pada organ vital. Operasi yang biasanya dilakukan dengan menggunakan anestesi umum di rumah sakit ruang operasi oleh tim dokter. Setidaknya pasien menjalani perawatan satu malam di rumah sakit setelah operasi.
Ada berbagai definisi dari operasi mayor, dan apa yang merupakan perbedaan antara operasi mayor dan minor. Sebagai aturan umum, yang utama adalah operasi besar dimana pasien harus diletakkan di bawah anestesi umum dan diberikan bantuan pernafasan karena dia tidak dapat bernafas secara mandiri. Operasi besar biasanya membawa beberapa derajat resiko bagi pasien hidup, atau potensi cacat parah jika terjadi suatu kesalahan selama operasi.

Hal ini di jelaskan dan dapat dikaitkan dengan hasil penelitian Wartawan (2012) selama tahun 2011 didapatkan sebanyak 335 orang pasien dirawat di bangsal bedah pasca tindakan operasi emergensi. Dari kelompok pasien tersebut 188 orang diantaranya pulang dalam waktu yang sesuai standar Depkes, yakni kurang dari 10 hari. Pada kelompok lain didapatkan sebanyak $1251 \quad(78,9 \%)$ pasien yang dirawat di bangsal tersebut menjalani operasi secara berencana. Dari analisa bivariat ternyata didapatkan hubungan bermakna antara sifat operasi dengan lamanya pasien dirawat di rumah sakit. Ini terbukti dari nilai sebesar 8,03 dan nilai $P$ value sama dengan 0,005 atau kurang dari 0,05 .

Menurut peneliti dari hasil penelitian yang di lakukan di ruang rawat inap bedah jenis operasi ada hubungan jenis operasi dengan lama perawatan pasca operasi karena resiko, keseriusan penyakit, bagian tubuh yang terkena, kerumitan operasi dan waktu pemulihan di ruang rawat inap dengan jenis operasi mayor lebih lama dirawat dibandingkan jenis operasi minor yang operasinya jarang menimbulkan komplikasi pasca operasi. Untuk itu diharapkan bagi tenaga kesehatan yang menangani dalam proses pembedahan atau operasi agar melaksanakan tugas sesuai dengan SOP, karena proses pembedahan dengan jenis operasi yang berbeda dapat mempengaruhi lama perawatan sehingga responden dapat dirawat sesuai dengan waktu yang tepat. 


\section{Hubungan Jenis Penyakit dengan Lama Perawatan Pasien Pasca Operasi}

Berdasarkan hasil penelitian pada tabel 3 menunjukkan bahwa responden terbanyak adalah lama rawat inap lebih dari 5 hari dengan penyakit kronis sebanyak $(74,1 \%)$ responden. Hasil penelitian ini bahwa pasien pasca operasi dengan penyakit kronis lebih cenderung lama rawat inap lebih dari 5 hari di ruang rawat inap bedah. Hasil uji statistik dengan menggunakan chi square diperoleh nilai $\rho$ value $=0,301$ yang berarti $\rho>a$, maka dapat disimpulkan bahwa tidak ada hubungan antara jenis penyakit dengan lama perawatan pasien pasca operasi di ruang rawat inap bedah Rumah Sakit Dr. H Abdul Moeloek.

Hal ini dapat ditunjukkan dari teori menurut Barbara J., 2008 \& Krzysztof, 2011 dalam Wartawan (2012) kasus yang akut dan kronis akan memerlukan lama hari rawat yang berbeda, dimana kasus yang kronis akan memerlukan lama hari rawat lebih lama dari pada kasus-kasus yang bersifat akut.

Hal ini tidak sejalan dengan hasil penelitian Yennya dan Elly Herwana (2006) meningkatnya prevalensi penyakit kronis terjadi seiring dengan bertambahnya usia. Berdasarkan laporan 50-80\% lansia yang berusia 65 tahun dan ke atas rata-rata akan mempunyai lebih dari satu penyakit kronis. Penyakit muskuloskeletal dilaporkan merupakan penyakit yang paling banyak ditemukan dan didapatkan merata pada setiap kelompok usia lansia. Berdasarkan survei kesehatan penyakit ini merupakan penyebab disabilitas pada populasi lansia. Pembatasan aktifitas fisik makin nyata bersamaan dengan penambahan usia. Berdasarkan laporan, $32 \%$ lansia berusia 70 tahun dan ke atas mengalami kesulitan untuk melakukan aktivitas fisik yang disebabkan penyakit muskuloskeletal. Bahkan lansia yang berusia $\geq 85$ tahun 2,6 kali lebih sering mengalami keterbatasan aktivitas fisik dibanding lansia berusia 70-74 tahun. Sedangkan dari studi ini diperoleh data keterbatasan fisik akibat penyakit muskuloskeletal terbanyak didapatkan pada kelompok usia yang jauh lebih muda yaitu pada kelompok usia 60-69 tahun sebesar $63 \%$.

Menurut peneliti dari hasil penelitian yang di lakukan di ruang rawat inap bedah. Dari responden dengan kasus yang penyakit akut dan penyakit kronis akan memerlukan lama hari rawat yang berbeda, dimana kasus yang kronis akan memerlukan lama hari rawat lebih lama dari pada kasus-kasus yang bersifat akut. Responden yang di rawat sebagian besar menggunakan jaminan kesehatan yang sudah di tentukan lama rawatnya pada setiap penyakit tertentu, sehingga hal tersebut dapat mempengaruhi lama rawat pasien. Untuk itu diharapkan agar petugas kesehatan dalam yang melakukan penanganan responden pasca operasi memprioritaskan diagnosa medis dan diagnosa perawat dengan proses pengkajian yang baik sehingga dapat menjadi landasan supaya dalam penanganan tindakan responden pasca operasi di ruang rawat inap dengan baik.

\section{Hubungan Umur Penderita dengan Lama Perawatan Pasien Pasca Operasi}

Berdasarkan hasil penelitian pada tabel 4 menunjukkan bahwa responden terbanyak adalah lama rawat inap lebih dari 5 hari dengan umur lebih dari 45 tahun sebanyak $(64,5 \%)$ responden. Hasil penelitian ini bahwa pasien pasca operasi dengan umur lebih dari 45 tahun lebih cenderung lama rawat inap lebih dari 5 hari di ruang rawat inap bedah. Hasil uji statistik dengan menggunakan chi square dapat diperoleh nilai yaitu $\rho$ value $=0,636$ yang berarti $\rho>a$, maka dapat disimpulkan bahwa tidak ada hubungan antara umur penderita dengan lama perawatan pasien pasca operasi di ruang rawat inap bedah Rumah Sakit Dr. H Abdul Moeloek.

Hal ini dapat ditunjukan teori menurut Herman C., 2009 dalam Wartawan (2012) dengan bertambahnya usia maka kemampuan sistem kekebalan tubuh seseorang untuk menghancurkan bakteri dan jamur berkurang. Disfungsi sistem imun dapat diperkirakan menjadi 
faktor di dalam perkembangan penyakit kronis seperti kanker, diabetes, dan penyakit kardiovaskuler serta infeksin. Pada beberapa penelitian, faktor umur mempengaruhi panjang lama hari rawat pasien bedah. Pasien yang sudah lanjut usia (diatas 45 tahun) cenderung lebih panjang lama hari rawatnya dibandingkan dengan pasien usia muda. Menurut Afif \& Ahmad, 2008 dalam Wartawan (2012) menemukan bahwa pasien usia 65 tahun keatas berpotensi memiliki lama hari rawat yang lebih panjang.

Hal ini sejalan dari hasil penelitian Wartawan (2012) bahwa tidak ada hubungan bermakna antara umur pasien dengan lama rawat pasien tersebut di rumah sakit dengan $P$ value 0,467 .Sebanyak 55,8\% atau 885 orang pasien bedah yang dirawat sepanjang tahun 2011 di bangsal bedah kelas III adalah mereka yang berumur di atas 45 tahun. Dilihat dari lama rawat di rumah sakit, tercatat 443 orang pasien di atas 45 tahun tersebut pulang sebelum 10 hari dan 442 pasien lainnya baru diijinkan pulang setelah 9 hari masa perawatan. Sedangkan kelompok pasien di bawah umur 46 tahun, 443 pasien tercatat boleh pulang sebelum 10 hari dan 363 pasien baru dibolehkan pulang setelah dirawat di rumah sakit selama 9 hari.

Menurut peneliti dari hasil penelitian yang di lakukan di ruang rawat inap bedah. Banyaknya responden dengan umur lebih dari atau 45 tahun yang ditemukan belum dapat dijadikan dasar responden lama dirawat pasca operasi. Pada responden yang umurnya kurang dari 45 tahun memang secara fisiologis akan lebih cepat sembuh daripada responden dengan umur lebih dari atau 45 tahun. Dengan bertambahnya usia maka kemampuan sistem kekebalan tubuh seseorang untuk menghancurkan bakteri dan jamur berkurang. Disfungsi sistem imun dapat diperkirakan menjadi faktor di dalam perkembangan penyakit. Bukan hanya bergantung dengan umur responden tetapi dengan pola gaya hidup yang berbeda juga dapat berpengaruh terhadap lama perawatan. Untuk itu diharapkan dalam melakukan tugas kesehatan pada responden tetap dalam proses yang sesuai dengan prosedur, fungsi dan tujuan yang sama walaupun dalam penanganan tetap berbeda sehingga responden dalam semua umur dapat dirawat dalam waktu yang tepat sesuai dengan kriteria umurnya.

\section{Hubungan Diagnosa Penyakit Penyerta Lama Perawatan Pasien Pasca Operasi}

Berdasarkan hasil penelitian pada tabel 5 menunjukkan bahwa responden terbanyak adalah lama rawat inap lebih dari 5 hari dengan tanpa diagnosa penyakit penyerta sebanyak $(59,6 \%)$ responden. Hasil penelitian ini bahwa pasien pasca operasi yang tanpa diagnosa penyakit penyerta lebih cenderung lama rawat inap lebih dari 5 hari di ruang rawat inap bedah. Hasil uji statistik dengan menggunakan chi square diperoleh nilai $\rho$ value $=0.049$ yang berarti $\rho<a$, makan dapat disimpulkan bahwa ada hubungan antara diagnosa penyakit penyerta dengan lama perawatan pasien pasca operasi di ruang rawat inap bedah Rumah Sakit Dr. H Abdul Moeloek, dengan nilai $\mathrm{OR}=6,786 \quad(0,801-57,478)$ artinya responden dengan diagnosa penyakit penyerta berpeluang 6,8 kali lebih lama perawatan pasca operasi diruang rawat inap bedah.

Dari hasil teori menurut Barbara J., 2008 \& Krzysztof, 2011 dalam Wartawan (2012) penyakit yang tunggal pada satu penderita akan mempunyai lama hari rawat lebih pendek dari pada penyakit ganda pada satu penderita.

Hal ini sejalan dengan hasil penelitian yang dilakukan oleh Imaniar N, Tri M \& Inayati (2012) distribusi pasien berdasarkan penyakit penyerta yang dialami pasien sebagian besar tanpa penyakit penyerta yaitu sebanyak 53 pasien $(77,94 \%)$, namun 15 pasien lainnya $(22,06 \%)$ memiliki penyakit penyerta seperti adanya diabetes pada 1 pasien $(1,47 \%)$, dan non diabetes pada 14 pasien $(20,59 \%)$. Namun berdasarkan hasil perhitungan statistik diperoleh hasil bahwa terdapat hubungan antara keberadaan penyakit penyerta dengan infeksi luka operasi $(\mathrm{p}<0,05)$. 
Menurut peneliti dari hasil penelitian yang di lakukan di ruang rawat inap bedah adanya hubungan antara diagnosa penyakit penyerta dengan lama perawatan pasca operasi. Responden yang diikuti dengan diagnosa penyakit penyerta akan lebih beresiko untuk menjalani masa perawatan yang lebih lama di ruang rawat inap daripada responden yang tidak diikuti diagnosa penyakit penyerta. Hal ini juga berkaitan penanganan responden yang diikuti dengan diagnosa penyerta, yakni akan membutuhan intensitas yang lebih tinggi. Dengan demikian di harapkan dalam melaksanakan tugas keperawatan berdasarkan tingkat ketergantungan pasien, sehingga dapat berjalan maksimal dengan asumsi akan dapat mengurangi lama hari perawatan.

\section{KESIMPULAN}

Penelitian menyimpulkan bahwa terdapat hubungan antara jenis operasi dengan lama perawatan pasien pasca operasi di ruang rawat inap bedah Rumah Sakit dengan $p$ value $=0,024$ dan terdapat hubungan antara diagnosa penyakit penyerta dengan lama perawatan pasien pasca operasi di ruang rawat inap bedah Rumah Sakit dengan $p$ value $=0,049$.

Hasil penelitian juga menyimpulkan tidak ada hubungan antara infeksi luka operasi dengan lama perawatan pasien pasca operasi di ruang rawat inap bedah Rumah Sakit dengan $p$ value $=0,114$, tidak ada hubungan antara jenis penyakit dengan lama perawatan pasien pasca operasi di ruang rawat inap bedah Rumah Sakit dengan $P$ value $=0,301$ dan tidak ada hubungan antara umur penderita dengan lama perawatan pasien pasca operasi di ruang rawat inap bedah Rumah Sakit dengan $P$ value $=0,636$.

Selanjutnya penulis menyarankan agar tenaga kesehatan yang menangani proses pembedahan agar melaksanakan tugas sesuai dengan SOP dan melaksanakan asuhan keperawatan berdasarkan tingkat ketergantungan pasien.

\section{DAFTAR PUSTAKA}

Kuraesin, N. D. (2009). Jurnal. FaktorFaktor yang Mempengaruhi Tingkat Kecemasan Pasien yang Menghadapi Operasi di RSUP Fatmawati 2009. http://repository. uinjkt.ac.id/dspace/bitstream/123456 789/2324/1/NYI\%20DEWI\%20KUR AESIN-FKIK.pdf diakses tgl 16 februari 2017.

Kusumayanti, P. D. (2015). Faktor-faktor yang berpengaruh terhadap lamanya perawatan pada pasien pasca operasi laparatomi. Coping ners (Community of Publishing in Nursing), 3(1). http://ojs.unud.ac.id/ index.php/coping/article/view/10812 Di akses tanggal 5 januari 2017

Pradita, N. A \& Jadmiko, A. W. (2016). Pengaruh Pemberian Terapi Musik Klasik Terhadap Tekanan Darah Dan Denyut Jantung Pasien Pasca Operasi Dengan Anestesi Umum Di RS Dr. Moewardi Surakarta (Universitas Muhammadiyah Surakarta). http://eprints.ums.ac.id/ $\underline{42065 /}$ diakses tanggal 5 januari 2017

Tedja, V. R. (2012). Hubungan Antara Faktor Individu, Sosio Demografi, Dan Administrasi Dengan Lama Hari Rawat Pasien Rawat Inap Rumah Sakit Pantai Indah Kapuk Tahun 2011. Universitas Indonesia. http://S3.amazonaws.com/academia. edu. Di akses Tanggal 20 Januari 2017.

Wartawan, I. W. (2012). Analisis Lama Hari Rawat Pasien yang Menjalani Pembedahan di Ruang Rawat Inap Bedah Kelas III RSUP Sanglah Denpasar Tahun 2011. Jakarta: Universitas Indonesia.

Yenny, \& Herwana, E. (2006). Jurnal. Prevalensi penyakit kronis dan kualitas hidup pada lanjut usia di Jakarta Selatan. http://www. univmed.org/wp-content/uploads/ 2012/04/Yenny.pdf diakses tgl 16 februari 2017. 